\title{
WHAT MAKES A GRAMMAR DIFFICULT? EXPERIMENTAL EVIDENCE
}

\author{
ARTURS SEMENUKS ${ }^{* 1}$, and ALEKSANDRS BERDICEVSKIS ${ }^{2}$ \\ *Corresponding Author: asemenuk@ucsd.edu \\ ${ }^{I}$ Department of Cognitive Science, University of California, San Diego, San Diego, USA \\ ${ }^{2}$ Department of Linguistics and Philology, Uppsala University, Uppsala, Sweden
}

It is sometimes argued that linguistic structure can be affected by extralinguistic factors (Ladd, Roberts \& Dediu, 2015). One specific hypothesis that has garnered a significant interest in the recent years links increase in the proportion of adult non-native (L2) learners in the population of a language to decrease in the morphological complexity of that language (Trudgill, 2011). Support for this view comes from qualitative typological analyses (Dahl, 2004; McWhorter, 2007; Trudgill, 2011), as well as correlational studies using both proxy (Lupyan \& Dale, 2010) and direct measures of L2 proportion in the population (Bentz \& Winter, 2013). This suggests that a greater L2 share in the population is associated with a higher probability of a language being analytic.

The exact details of how and why increased number of adult learners in the population can lead to morphological simplification, however, are not yet fully fleshed out. One hypothesis proposes that the simplification crucially depends on the cognitive differences between children and adults (Lupyan \& Dale, 2010), as adults experience more difficulties learning morphology (DeKeyser, 2005). These difficulties, in turn, lead to the simplification of morphology.

McWhorter (2001) argues that grammars of creoles predominantly use analytic or isolating strategies, but an analytic morphosyntax by itself does not imply that a language had been affected by L2 speakers. However, his qualitative analyses do suggest that older non-creole languages have more grammatical distinctions compared to creoles (McWhorter, 2001). This begs the question of what exactly is more difficult for L2 speakers, and thus more likely to change in a contact situation: how many grammatical categories a language has or how complex the expression of these categories is (i.e. fusional is more difficult than agglutinative)?

To investigate this, we designed an artificial language (AL) learning experiment in which we manipulated the number of grammatical distinctions and the way they are expressed in the AL, and measured how these differences 
affected the AL learning time. Native English speakers learned an AL that mapped onto intransitive English sentences with pronoun subjects, e.g. "I am walking". We separately manipulated (i) whether the pronoun was agglutinated to the verb and (ii) whether number was expressed fusionally, agglutinatively or not expressed at all in the AL, for a total of six conditions (Table 1). Thus four of the conditions expressed two grammatical categories and differed in the morphological complexity of their expression, and the two remaining conditions expressed only one category and differed in the complexity of its expression.

\begin{tabular}{|c|c|c|c|}
\hline & $\begin{array}{l}\text { Number \& } \\
\text { person fused }\end{array}$ & $\begin{array}{l}\text { Number \& person } \\
\text { agglutinated }\end{array}$ & $\begin{array}{c}\text { Number } \\
\text { absent }\end{array}$ \\
\hline $\begin{array}{l}\text { Pronoun \& verb } \\
\text { agglutinated }\end{array}$ & $\begin{array}{l}\text { (1) potujota } \\
\text { (2) lewujota }\end{array}$ & $\begin{array}{l}\text { (1) pujota } \\
\text { (2) pubijota }\end{array}$ & $\begin{array}{l}\text { (1) pujota } \\
\text { (2) pujota }\end{array}$ \\
\hline $\begin{array}{r}\text { Pronoun \& verb } \\
\text { isolated }\end{array}$ & $\begin{array}{l}\text { (1) potu jota } \\
\text { (2) lewu jota }\end{array}$ & $\begin{array}{l}\text { (1) pu jota } \\
\text { (2) pubi jota }\end{array}$ & $\begin{array}{l}\text { (1) pu jota } \\
\text { (2) pu jota }\end{array}$ \\
\hline
\end{tabular}

Table 1. Translations of example English sentences (1) "I am walking" and (2) "We are walking" in different experimental conditions.

The experiment continued until the participant made no mistakes in translating from English to AL. The number of rounds this took was measured. At the end, all of the participants translated six novel sentences, which served as a check for whether they truly learned the underlying generative rules of the language.

We recruited 48 participants per condition (288 total). ANOVAs showed that only the number of grammatical categories, but not the complexity of their expression, affected the learning time - ALs that did not encode number were learned faster. This held true both overall, as well as only in the data from participants that translated all novel sentences correctly (Figure 1). The results hint at the possibility that the difficulties in L2 learning are caused primarily by the number of grammatical categories, and not their morphological expression per se, which gives rise to the patterns observed in the studies discussed above.

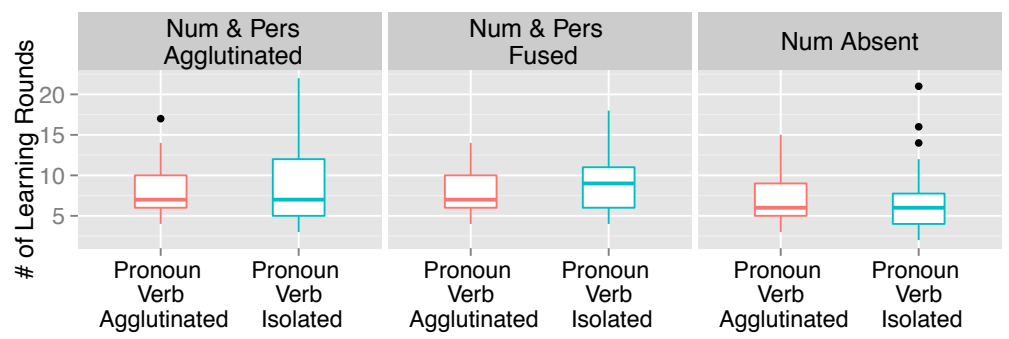

Figure 1. Median numbers of learning blocks in different conditions for participants who were able to fully learn the language and generate novel sentences correctly. 


\section{References}

Bentz, C., \& Winter, B. (2013). Languages with more second language learners tend to lose nominal case. Language Dynamics and Change 3(1), 1-27.

Dahl, Ö. (2004) The growth and maintenance of linguistic complexity. Amsterdam: John Benjamins Publishing.

DeKeyser, R. M. (2005) What Makes Learning Second-Language Grammar Difficult? A Review of Issues. Language Learning 55, 1-25.

Ladd, D. R., Seán G. R., \& Dediu, D. (2015) Correlational studies in typological and historical linguistics. Annual Review of Linguistics 1, 221-241.

Lupyan, G., \& Dale, R. (2010) Language structure is partly determined by social structure. PLoS ONE 5(1), e8559.

McWhorter, J. H. (2001). The world's simplest grammars are creole grammars. Linguistic typology, 5(2), 125-66.

McWhorter, J. H. (2007) Language interrupted: Signs of non-native acquisition in standard language grammars. Oxford: Oxford University Press.

Trudgill, P. (2011) Sociolinguistic typology: Social determinants of linguistic complexity. Oxford: Oxford University Press. 